Syntax Literate: Jurnal Ilmiah Indonesia p-ISSN: 2541-0849

e-ISSN: 2548-1398

Vol. 6, No. 2, Februari 2021

\title{
ANALISIS PENGETAHUAN MASYARAKAT TENTANG PERBANKAN SYARIAH
}

\section{Dicky Fauzi Firdaus dan Tuti Alawiyah}

Universitas Islam Al-Ihya (UNISA) Kuningan, Jawa Barat, Indonesia

Email: df.firdaus.20@gmail.com dan alawiyahtuti922@gmail.com

\section{Abstract}

The development and growth of Islamic banks still receive less attention from the public. This study aims to determine the description of public knowledge about Islamic banking. What is meant here is knowledge about public knowledge about Islamic banks in general and the difference with conventional banks, public knowledge about Islamic bank products and services, as well as sources of information about Islamic banks that people get. This study uses a qualitative method. Techniques for collecting data use surveys and interviews. The technique for taking samples is random sampling, which gives equal rights to each subject to get the chance to be chosen as a sample, the sample is taken randomly. The results of the study indicate that public knowledge about Islamic banks is still low, namely at the level of knowing, where people only know about the existence of Islamic banks but do not know more about Islamic banks, especially in products contained in Islamic banks. The community considers that the difference between Islamic banks and conventional banks lies in interest, but the public also does not fully believe that Islamic banks are free from usury. The interview results show that the lack of public knowledge is caused by the lack of socialization and product offerings from the Islamic banks themselves, besides the distance or long distance.

Keywords: knowledge; society; islamic bank

\section{Abstrak}

Perkembangan dan pertumbuhan bank syariah masih mendapatkan perhatian yang kurang dari masyarakat. Penelitian ini bertujuan untuk mengetahui gambaran pengetahuan masyarakat tentang perbankan syariah. Pengetahuan disini adalah tentang pengetahuan masyarakat mengenai bank syariah secara umum dan perbedaannya dengan bank konvensional, pengetahuan masyarakat mengenai produk dan jasa bank syariah, juga sumber informasi tentang bank syariah yang masyarakat dapatkan. Penelitian ini menggunakan metode kualitatif. Teknik untuk mengumpukan data menggunakan survei dan wawancara. Teknik untuk mengambil sampel adalah random sampling, yaitu memberikan hak yang sama kepada setiap subyek untuk mendapatkan kesempatan dipilih sebagai sampel yang diambil secara acak. Hasil penelitian menunjukkan bahwa pengetahuan masyarakat tentang bank syariah masih rendah, yaitu pada tingkatan tahu, dimana masyarakat hanya sekedar tahu mengenai adanya bank syariah tapi tidak mengetahui lebih jauh tentang bank syariah terutama pada produk yang terdapat di bank syariah. Masyarakat menganggap bahwa perbedaan bank syariah dan bank konvensional terletak pada 
bunga, akan tetapi masyarakat juga belum sepenuhnya meyakini bahwa bank syariah sudah bebas dari riba. Hasil wawancara menunjukkan bahwa rendahnya pengetahuan masyarakat disebabkan tidak adanya sosialisasi dan penawaran produk dari pihak bank syariah sendiri, selain itu jarak tempuh atau akses yang jauh.

Kata Kunci: pengetahuan; masyarakat; bank syariah

Coresponden Author

Email: df.firdaus.20@gmail.com

Artikel dengan akses terbuka dibawah lisensi

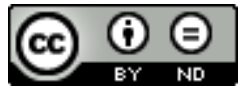

\section{Pendahuluan}

Perkembangan bank syariah di Indonesia secara umum cukup menggembirakan, ini ditandai dengan semakin dikenalnya bank syariah secara nasional. Sebagai suatu yang tergolong baru, keberadaan bank syariah dan produk-produknya tentu akan menjadi pilihan yang mungkin diminati dan mungkin tidak diminati. Apalagi nama produk yang dijual oleh bank syariah dengan menggunakan istilah yang mungkin sulit untuk dilafalkan, sedangkan pada perbankan konvensional masyarakat sudah mengenal, sehingga masyarakat lebih berminat untuk melakukan transaksi di perbankan konvensional.

Masyarakat dalam pengertian ekonomi adalah individu, lembaga dan badan. Individu dapat berupa penduduk domestik atau orang asing, lembaga dan badan dapat berupa swasta maupun pemerintah. Masyarakat yang menyimpan dananya di bank dengan berbagai motif, seperti motif berjaga-jaga, motif transaksi untuk memudahkan pembayaran, dan ketiga dengan motif mendapatkan keuntungan (Sudirman, 2013).

Ada banyak faktor yang mempengaruhi masyarakat dalam memilih bank sebagai sumber pendanaan yang mereka butuhkan. Faktor tingkat suku bunga, jumlah kredit yang diberikan serta nilai agunan yang dipersyaratkan menjadi faktor utama yang mempengaruhi masyarakat. Kemudian diikuti faktor administrasi dan kredibilitas bank itu sendiri dan lingkungan masyarakat menjadi faktor terakhir (Nababan \& Ritonga, 2013).

Secara umum bank syariah sudah dikenal oleh masyarakat terutama yang tinggal diperkotaan, selain itu juga masyarakat kalangan menengah dan masyarakat kecil. Akan tetapi masih banyak masyarakat yang belum mengetahui tentang bank syariah. Secara teori bank syariah dan bank konvensional berbeda, bank konvensional beroperasi dengan sistem bunga sedangkan bank syariah beroperasi dengan sistem bagi hasil. Meskipun begitu masih banyak masyarakat yang belum tahu tentang bank syariah. Secara kasat mata yang peneliti lihat kebanyakan masyarakat pada lokasi penelitian belum banyak yang mengetahui tentang bank syariah. Sebagian dari mereka masih menyamakan bank syariah dengan bank konvensional tidak memiliki perbedaan. Mereka 
juga lebih sering menggunakan jasa bank konvensional walaupun agama mereka mayoritas Islam.

Bank syariah masih dapat terus berkembang, jika mendapatkan dukungan tidak hanya dari pihak pemerintah tetapi juga masyarakat. Semakin banyak masyarakat yang menggunakan jasa dan produk bank syariah maka bank syariah dapat terus tumbuh dan market share bank syariah juga berkembang. Oleh karena itu penting bagi masyarakat untuk mengetahui tentang bank syariah. Pengetahuan masyarakat tentang bank syariah dapat meningkatkan pemahaman masyarakat tentang bank syariah.

Pengetahuan adalah hasil dari tahu, ini diperoleh setelah melakukan penginderaan terhadap suatu objek dengan panca indera, seperti penglihatan, pendengaran, penciuman, rasa dan raba. Pengetahuan manusia sebagian besar didapat dari panca indera penglihatan dan pendengaran. Hasil penginderaan manusia dipengaruhi oleh intensitas perhatian dan persepsi terhadap objek (Notoatmodjo, 2005).

Menurut (Notoatmodjo, 2005) mengatakan pengetahuan merupakan domain kognitif dan pengetahuan terhadap suatu objek memiliki tingkatan yang berbeda-beda. Secara garis besar pengetahuan memiliki 6 (enam) tingkatan: (1) Tahu hanya diartikan sebagai recall (memanggil) memori yang sebelumnya telah tersimpan setelah melakukan pengamatan terhadap suatu objek tertentu. Tahu adalah tingkatan pengetahuan yang paling rendah. Kata kerja yang digunakan untuk mengukur tingkatan ini seperti menyebutkan, mendefinisikan, menyatakan dan sebagainya. (2) Memahami (Comprehension), di sini tidah hanya sekedar tahu, tetapi mampu menjelaskan secara benar tentang suatu objek yang diketahui. Seperti mampu menyimpulkan, memberikan contoh, dan sebagainya. (3) Aplikasi (Aplication) aplikasi dapat diartikan sebagai kemampuan untuk menggunakan materi atau pengetahuan yang dimiliki pada kondisi nyata tertentu yang sesuai. (4) Analisis (Analysis) analisis ialah kemampuan menjabarkan suatu objek ke dalam komponen-komponen, tetapi masih satu struktur organisasi dan saling berhubungan satu sama lain. Seperti membuat bagan, membedakan dan lainnya. (5) Sintesis (Synthesis) sintesis dapat diartikan sebagai kemampuan menyusun formulasi yang baru dari formulasi yang telah ada. Seperti dapat menyusun, meringkas materi yang sudah dibaca dengan kata-kata yang ada atau kata-kata sendiri. (6) Evaluasi (Evaluation) evaluasi berkaitan dengan kemampuan justifikasi atau melakukan penilaian terhadap suatu objek yang didasarkan pada kriteria tertentu yang telah ditentukan sebelumnya.

Menurut Undang-undang nomor 21 tahun 2008 pasal 1, perbankan syariah adalah segala sesuatu yang menyangkut tentang bank syariah dan unit usaha syariah, mencakup kelembagaan, kegiatan usaha, serta cara dan proses dalam melaksanakan kegiatan usahanya (Wiroso, 2011). Menurut (Akhmad, 2016) dalam bukunya yang berjudul "Hukum Perbankan Syariah" menjelaskan bahwa pada bank syariah, penyaluran dana lebih berdasar pada pertimbangan profitabilitas suatu proyek yang hendak dibiayai. Sedangkan pada bank konvensional mementingkan jaminan pengembalian nilai nominal plus bunga, sekalipun profitabilitas proyek kurang meyakinkan. Menurut (Hasan, 2014) terdapat beberapa perbedaan bank syariah dan bank konvensional, yaitu dari segi akad, 
segi pembiayaan, segi sumber dana bank syariah, adanya Dewan Pengawas Syariah (DPS), adanya Dewan Syariah Nasional (DSN), adanya lembaga penyelesaian sengketa (BASYARNAS), serta lingkungan kerja islami dan corporate culture.

Dalam sistem perbankan syariah, terdapat beberapa produk yang dioperasikan atau diaplikasikan dalam kehidupan sosial ekonomi masyarakat. Menurut (Hasan, 2014) produk perbankan syariah dibagi menjadi 3 (tiga) bagian, yaitu: (1) produk simpanan (funding), penghimpunan dana di bank syariah dapat berbentuk giro, tabungan dan deposito. Prinsip operasional syariah yang diterapkan dalam penghimpunan dana masyarakat adalah menggunakan akad wadi'ah dan mudharabah. Produknya antara lain Giro, tabungan, dan deposito. (2) produk pembiayaan (financing), Dalam sistem perbankan Islam, kredit lebih diartikan dengan pembiayaan. Dalam sistem pembiayaan ini terdapat beberapa konsep yang diterapkan oleh bank syariah dalam memberikan modal ataupun pembiayaan bagi nasabah perbankan, antara lain dengan menggunakan sistem kerjasama atau bagi hasil sistem pemberian barang modal dan sistem pemberian barang konsumtif. Contoh produknya antara lain pembiayaan modal usaha, pembiayaan barang modal dan barang konsumtif, pembiayaan dengan sistem sewa (Operational Lease and Financial Lease) dan (3) produk jasa (fee-based service). Produk Jasa (FeeBased Service) pelayanan jasa bank merupakan produk jasa bank yang diberikan kepada nasabah untuk memenuhi kebutuhannya. Bank menawarkan produk jasa dengan tujuan untuk memberikan pelayanan kepada nasabah bank atau pihak lain yang memerlukannya. Dengan memberikan pelayanan jasa bank, maka bank akan memperoleh pendapatan yang diperoleh bank yang berasal dari pendapatan atas produk jasa disebut dengan fee based income. Menurut (Ismail, 2014; Karim, 2017) terdapat beberapa akad dalam produk jasa bank syariah yaitu: wakalah, kafalah, hawalah, rahn, qard, dan sharf. Penelitian Sitorus (2019) bahwa produk perbankan syariah adalah kurangnya kesadaran masyarakat untuk mengenalinya, jaringan operasional bank syariah yang terbatas, dan kurangnya sosialisasi kepada masyarakat. Hal ini sejalan dengan penelitian yang dilakukan saat ini.

\section{Metode Penelitian}

Jenis penelitian ini merupakan sebuah penelitian deskriptif dengan pendekatan kualitatif. Adapun objek dalam penelitian ini adalah perbankan syariah. Sumber data ada 3 (tiga) yaitu: pertama person (orang), merupakan tempat dimana peneliti bertanya mengenai variabel yang diteliti, kedua paper (kertas), adalah tempat peneliti membaca dan mempelajari segala sesuatu yang berhubungan dengan penelitian, seperti arsip, angka, gambar, dokumen-dokumen, simbol-simbol, dan lain sebagainya, ketiga place (tempat), yaitu tempat berlangsungnya kegiatan yang berhubungan dengan penelitian. Jenis data yang dikumpulkan dalam penelitian ini adalah data primer dan data sekunder. Teknik analisis data antara lain reduksi data, penyajian data, dan penarikan kesimpulan. 


\section{Hasil dan Pembahasan}

Sebenarnya masyarakat sudah mengetahui adanya perbankan syariah. Masyarakat memiliki alternatif lain selain bank konvensional untuk memenuhi kebutuhan mereka, seperti menabung, melakukan pembiayaan untuk modal usaha. Serta memanfaatkan jasa yang diberikan oleh perbankan syariah.

Pertama adalah terkait pengetahuan informan mengenai perbankan syariah. 5 (lima) dari 9 (sembilan) informan yang peneliti wawancara telah mengetahui adanya bank syariah dan mengetahui definisi bank syariah, 3 informan selanjutnya hanya sekedar menghetahui adanya bank syariah tapi tidak mengetahui definisi bank syariah itu sendiri, dan 1 informan lagi menurut pengakuannya sama sekali belum pernah mendengar tentang bank syariah. Kedua, terkait pengetahuan informan tentang keberadaan bank syariah di Kuningan rata-rata informan lebih mengetahui ke bank Muamalat, sedangkan untuk bank BRIS, BSM, BJB Syariah, hanya beberapa informan saja yang mengetahui, bahkan untuk BNI Syariah hanya satu orang yang mengetahuinya yaitu Sdr. Dewi. Disamping itu kebanyakan masyarakat hanya tau nama bank nya saja tetapi tidak tahu letak bank tersebut di daerah Kuningan, bahkan ada salah satu informan yaitu Sdr. Dede mengira bahwa bank BRI yang di Cilimus adalah Bank BRI Syariah, padahal di Kuningan sendiri baru ada satu KCP BRIS yaitu di sebelah barat taman kota Kuningan. Ketiga, terkait pengetahuan masyarakat tentang perbedaan bank syariah dan bank konvensional, rata-rata informan menjawab perbedaannya terletak pada bunga, dimana menurut informan bunga pada bank syariah lebih kecil dibandingkan bank konvensional, informan juga menjelaskan bahwa bank syariah tidak terlalu riba dibandingkan dengan bank konvensional. Selain itu ada 2 (dua) orang informan yang menjelaskan bahwa perbedannya juga terletak pada akad atau ijab qobul serta pada operasionalnya. Tetapi 4 (empat) informan dari 9 (sembilan) informan yang peneliti wawancara tidak mengetahui perbedaan bank syariah dan bank konvensional. Lebih lanjut lagi salah satu informan menjelaskan bahwa bank syariah dan bank konvensional berbeda, bank syariah menggunakan sistem bagi hasil yang berarti kedua pihak siap kehilangan dana yang digunakan untuk usaha bersama. Sedangkan bank biasa atau konvensional tidak melihat kerugian yang dialami oleh rekan kerjanya atau nasabah, sehingga bank konvensional tetap mendapatkan keuntungan meskipun nasabahnya mengalami kerugian.

Keempat, mengenai pengetahuan masyarakat tentang bunga dan bagi hasil, ratarata informan menjawab bahwa bunga adalah tambahan dari pinjaman pokok nasabah kepada pihak bank, sedangkan bagi hasil adalah keuntungan yang dibagi dua atau sesuai kesepakan kedua belah pihak. Tetapi 3 (tiga) informan dari 9 (sembilan) informan yang peneliti wawancara mengaku tidak mengetahui arti dari bunga dan bagi hasil. Keenam, terkait pendapat masyarakat tentang kesyariahan bank syariah, lima informan berpendapat bahwa bank syariah sudah lebih bagus jika dibandingkan dengan bank konvensional. Meskipun belum yakin $100 \%$ persen kegiatan bank syariah sesuai dengan syariah, tetapi sebagai seorang muslim, bank syariah dapat menjadi alternatif untuk memenuhi kebutuhan yang berhubungan dengan lembaga keuangan. Satu informan 
mengatakan secara teori bank syariah sudah sesuai dengan prinsip syariah, tetapi untuk praktek, informan masih belum yakin. Satu informan mengatakan kegiatan pendanaan (simpanan) sudah sesuai dengan syariah, tidak lagi menggunakan bunga. Sedangkan untuk penyaluran dana (pembiayaan) masih mengandung unsur bunga sedikit atau dengan kata lain belum $100 \%$ sesuai dengan prinsip syariah. Produk pembiayaan masih mengandung unsur bunga, tetapi besar bunga pada bank syariah tidak sebesar bunga bank konvensional.

Berdasarkan hasil wawancara yang telah dilakukan hasil penelitian ini selaras dengan penelitan (Ahyar, 2017), bahwa dewan guru pondok pesantren masih memiliki keraguan terhadap kesyariahan produk perbankan syariah. Lebih lanjut dikatakan produk perbankan syariah yang belum bisa sesuai dengan syariah adalah produk penyaluran dana. Analisis yang dilakukan di atas pendapat informan hampir sama dengan penelitian (Ghafur, 2007) pengetahuan masyarakat tentang bank syariah masih relatif rendah. Informan baru sekedar tahu saja, dan mereka belum dapat memahami bank syariah secara mendalam. Dijelaskan pula oleh Bapak Nurhadi selaku bagian Ekonomi Pembangunan Desa Timbang, bahwa pengetahuan tentang bank syariah pada masyarakat desa Timbang relatif rendah, masyarakat lebih sering melakukan transaksi keuangan dengan bank BRI, baik itu untuk menabung, transfer ataupun pinjaman modal usaha. Bahkan masih banyak pula masyarakat yang menggunakan jasa rentenir untuk meminjam uang, dengan alasan persyaratan yang mudah dan tidak pakai agunan. (Wawancara tanggal 18 September 2019 dengan Bapak Nurhadi, Aparat desa Timbang Bagian Ekonomi Pembangunan).

Pengetahuan informan tentang produk perbankan syariah masih rendah, belum terlalu luas. Padahal produk perbankan bervariasi dan memiliki keunggulan serta memiliki kemudahan yang dapat diperoleh dari produk perbankan terutama produk perbankan syariah. Nasabah dapat menentukan produk perbankan syariah yang sesuai dengan kemampuan dan kebutuhan nasabah jika dapat memahami produk-produk perbankan syariah lebih mendalam atau luas lagi. Tetapi ada satu informan yang mengetahui dengan jelas produk dan akad yang informan gunakan di bank syariah, ketika ditanya terkait produk dan akad yang digunakan informan menjelaskan dengan jelas dan detail. Selebihnya, informan yang lain hanya mengetahui produk yang mereka gunakan saja, pengetahuan itu juga masih terbatas. Informan tidak mengetahui secara detail tentang produk yang mereka gunakan. Hasil penelitian ini sejalan dengan penelitian (Isa, 2017) yang menyatakan pengetahuan masyarakat tentang produk dan jasa perbankan syariah masih rendah. Tidak hanya produk dan jasa bank syariah yang kurang diketahui informan. Akad yang digunakan dalam perbankan syariah atau produk bank syariah yang digunakan juga tidak diketahui. Akad yang digunakan dalam produk pendanaan dan pembiayaan bank syariah dapat dilihat pada bab dua kajian teori. Informan sendiri tidak pernah membaca secara teliti perjanjian yang dibuat pada awal akad, padahal jika dibaca akan ada manfaat yang akan diperoleh informan. Selain itu, informan juga tidak menanyakan hal tersebut kepada petugas bank syariah. Bahkan ada informan mengatakan bahwa petugas bank syariah juga tidak menjelaskan hal tersebut. 
Pihak bank seharusnya memberikan pembekalan terhadap karyawannya terutama karyawan yang bekerja sebagai customer service dan marketing. Marketing seharusnya dapat memberikan penjelasan kepada nasabah tentang produk tersebut termasuk akad yang digunakan. Marketing harus menghindari pemakain kata bunga saat menawarkan produk. Jangan seakan-akan mendapat bunga sekian, tapi harus dirubah dan dibiasakan misalnya, tabungan ini nanti akan mendapatkan bonus atau bagi hasil, dan lain-lain. Dengan demikian pengetahuan masyarakat tentang produk dan jasa bank syariah dapat bertambah luas dan semakin banyak nasabah bank syariah. Hasil penelitian di atas sama dengan penelitian (Hasanah, 2013; Kristiani, Anema, 2016) Hasil penelitian keduanya mengatakan bahwa masyarakat yang sudah mengetahui bank syariah masih belum sepenuhnya mengetahui tentang produk dan jasa perbankan syariah.

Pengalaman informan dalam menggunakan lembaga keuangan khususnya lembaga keuangan syariah. Seluruh informan merupakan nasabah bank konvensional, akan tetapi hanya 3 (tiga) informan dari 9 (sembilan) informan yang peneliti wawancara mengaku merupakan nasabah bank syariah juga, itupun 2 (dua) orang informan menggunakan produk bank syariah hanya untuk keperluan tabungan haji yang dilakukan beberapa tahun lalu. Satu informan mengaku masih menjadi nasabah aktif di bank syariah. 3 (tiga) informan tidak menjawab atau bingung untuk memilih menggunakan produk bank syariah atau bank konvensional, 1 (satu) informan mengaku tidak ingin menggunakan keduanya karena sama-sama terdapat riba, 4 (empat) informan mengaku ada keinginan untuk menabung di bank syariah tapi terhambat beberapa kendala jarak tempuh dan fasilitas ATM. Satu informan dengan sangat tegas lebih memilih bank syariah karena biaya admin tabungan lebih rendah. Selanjutnya, Informan Sdr. Ita Asmita menuturkan ingin memakai produk bank syariah jika aksesnya dekat dan persyaratnya tidak ribet, dan bungnya lebih rendah. Penelitian ini juga sejalan dengan hasil penelitian (Nababan \& Ritonga, 2013) yang berjudul Analisis FaktorFaktor yang Mempengaruhi Keputusan Dalam Memilih Lembaga Keuangan Sebagai Sumber Pendanaan mengatakan sistem adminitrasi, agunan dan kredibilitas lembaga keuangan mempengaruhi masyarakat dalam memilih bank sebagai sumber pendanaan mereka, yang paling utama adalah tingkat suku bunga. Berbeda halnya dengan informan Sdr. Asmalinda yang juga menggunakan produk bank syariah dan bank konvensional, informan menjelaskan bahwa informan tertarik untuk menggunakan bank syariah hanya saja akses yang jauh sehingga dirasa menyulitkan informan dalam bertransaksi karena informan harus turun naik kendaraan umum untuk sampai di bank. Hal ini juga sesuai dengan pernyataan Bapak Nurhadi, dimana beliau mengatakan bahwa salah satu faktor yang menyebabkan masyarakat belum memilih bank syariah sebagai pilihan transaksi keuangan adalah karena jarak bank syariah yang susah dijangkau, atau terlalu jauh dari desa Timbang, sehingga menyulitkan masyarakat untuk bisa dengan mudah mengakses urusan keuangan di bank syariah. (Wawancara tanggal 18 September 2019 dengan Bapak Nurhadi, Aparat desa Timbang Bagian Ekonomi Pembangunan) 
Terkait tentang adanya sosialisasi atau edukasi dan penawaran produk bank syariah kepada masyarakat, berdasarkan hasil wawancara dengan informan, mereka mengatakan belum pernah mengikuti edukasi atau sosialisasi tentang lembaga keuangan syariah khususnya tentang perbankan syariah. Informan mendapatkan informasi tentang bank syariah dari teman, keluarga atau tetangga dan berita tv maupun sosial media. Informan juga mnegaku bahwa mereka menggunakan produk bank syariah atas dasar informasi dari keuarga dan temannya. Baik pihak Otoritas Jasa Keuangan (OJK) maupun perbankan syariah belum pernah mengadakan kegiatan edukasi dan sosialisasi tentang perbankan syariah. Bapak Nurhadi juga menjelaskan bahwa belum pernah ada sosialisasi tentang bank syariah di desa Timbang, dan beliau mengharapkan akan adanya sosialisasi tentang bank syariah di tengah masyarakat, agar masyarakat bisa lebih teredukasi dan terbuka wawasannya mengenai hakikat-hakikat ek onomi Islam yang seharusnya juga sedikit demi sedikit masyarakat bisa menghindari pinjaman kepada rentinir. Bapak Nurhadi juga berharap adanya cabang atau koperasi syariah yang dekat dengan masyarakat yang memakai sistem sesuai syariat Islam tetapi dengan syarat dan ketentuan yang mudah dan tidak membebankan masyarakat. (Wawancara tanggal 18 September 2019 dengan Bapak Nurhadi, Aparat desa Timbang Bagian Ekonomi Pembangunan). Hal baru yang ada di penelitian ini adalah bisa mengetahui sampai sejauh mana pengetahuan tentang perbankan syariah khususnya masyarakat Desa Timbang Kecamatan Cigandamekar Kabupaten Kuningan serta bisa dijadikan tolok ukur untuk pengembangan dunia perbankan syariah kedepannya.

\section{Kesimpulan}

Pengetahuan masyarakat tentang bank syariah dan perbedaannya dengan bank konvensional masih tergolong rendah. Hal ini terlihat dari wawancara yang dilakukan selama waktu penelitian dan menganggap sama tentang perbankan syariah dan bank konvesional, padahal ada perbedaannya yaitu dari sistem bunga, produk, dan kegiatan operasionalnya.

Pengetahuan masyarakat tentang produk dan akad bank syariah masih rendah. Terlihat masih banyak informan yang menjadi nasabah bank konvensional dibandingkan dengan perbankan syariah sehingga yang mereka ketahui produk-produk bank konvensional saja. 


\section{BIBLIOGRAFI}

Ahyar, M. Khozin. (2017). Literasi Keuangan Syariah Dalam Konteks Pondok Modern (STudi Ksus Pondok Modern Asy-Syifa Balikpapan). Surakarta: Institut Agama Islam Negeri Surakarta.

Akhmad, Mujahidin. (2016). Hukum perbankan syariah. Jakarta: PT. Rajagrafindo Persada.

Ghafur, Muhammad. (2007). Potret Perbankan Syariah Indonesia Terkini (Kajian Kritis Perkembangan Perbankan Syariah). Yogyakarta: Biruni Press.

Hasan, Ichsan W. (2014). Perbankan Syariah (sebuah praktek). Referensi (Gaung Persada Press Group).

Hasanah, Wirdatul. (2013). Tingkat Pengetahuan Masyarakat Terhadap Produk Perbankan Syariah Di Kelurahan Langgini Kota Bangkinang Kabupaten Kampar. Universitas Islam Negeri Sultan Syarif Kasim Riau.

Isa, Muhammad. (2017). Pengetahuan Masyarakat Desa Hutatonga Kecamatan Panyabungan Barat Tentang Perbankan Syariah. Jurnal At-Tijaroh, 3(2).

Ismail. (2014). Perbankan Syariah. Jakarta: Kencana Prenadamedia Group.

Karim, Adiwarman A. (2017). Bank Islam: Analisis Fiqih Dan Keuangan Ed 5.Jakarta: Raja Grafindo.

Kristiani, Anema, dan Wahyu. (2016). Analisis Tingkat Pemahaman Masyarakat Terhadap Produk Keuangan Di Deli Serdang. Jurnal Ekonomi dan Keuangan, 2(7).

Nababan, Denisa Irawaty, \& Ritonga, Haroni Doli. (2013). Analisis Faktor-Faktor yang Mempengaruhi Keputusan Masyarakat Kecamatan Medan Helvetia Dalam Memilih Lembaga Keuangan Sebagai Sumber Pendanaan. Jurnal Ekonomi dan Keuangan, 1(6), 14746.

Notoatmodjo, Soekidjo. (2005). Metodologi Penelitian Kesehatan. Cetakan ketiga. Jakarta. PT. Rineka Cipta.

Sitorus, Frisa Silwy. (2019). Analisis Tingkat Pengetahuan Masyarakat Terhadap Produk Perbankan Syariah Di Kelurahan Pematang Pasir Kecamatan Teluk Nibung Kota Tanjungbalai. Skripsi: Perbankan Syariah Fakultas Ekonomi dan Bisnis Islam UIN Sumtera Utara.

Sudirman, I. Wayan. (2013). Manajemen Perbankan Menuju Bankir Konvensional yang Profesional.Jakarta: Kencana

Sugiono. (2011). Metode Penelitian Kuantitatif, Kualitatif dan R\&D. Cetakan Ketiga Belas. Bandung: Penerbit Alfabeta. 
Analisis Pengetahuan Masyarakat Tentang Perbankan Syariah

Sugiyono. (2016). Metode Penelitian Kuantitatif, Kualitatif, dan R\&D. Bandung: Alfabeta.

Wiroso, Wiroso. (2011). Produk Perbankan Syariah. LPFE Usakti. 